\title{
INFLUENCE OF DIAMETER AND GEOMETRY IN THE TAPPING OF THE PILOT HOLE IN PEDICLE SCREWS
}

\author{
INFLUÊNCIA DO DIÂMETRO E GEOMETRIA NO MACHEAMENTO DO ORIFÍCIO PILOTO \\ NOS PARAFUSOS PEDICULARES
}

\author{
INFLUENCIA DEL DIÁMETRO Y GEOMETRÍA EN EL TALADRAMIENTO DEL AGUJERO \\ PILOTO EN TORNILLOS PEDICULARES
}

Helton luiz Aparecido Defino, ${ }^{1,2}$ Raffaello de Freitas Miranda, ${ }^{1}$ Romulo Pedroza Pinheiro², Antonio Carlos Shimano

1. Universidade de São Paulo, Hospital das Clínicas, Spine Group, Ribeirão Preto, SP, Brazil.

2. Universidade de São Paulo, Faculdade de Medicina, Hospital das Clínicas, Biomechanics, Medicine, and Locomotor Apparatus Rehabilitation Department, Ribeirão Preto, SP, Brazil.

\begin{abstract}
Objective: To evaluate the insertion torque and the pulling force of each screw with different diameters and tap. Methods: Polyurethane blocks with a pilot hole of $2.7 \mathrm{~mm}$ were used in the study. An experimental group with 5 blocks was formed, the insertion torque was evaluated with a torque meter, and the pullout strength of each Globus screw of $5.5 \mathrm{~mm}$ and $6.5 \mathrm{~mm}$ was assessed. Results: The comparison of the insertion torque on the $5.5 \mathrm{~mm}$ screws with pilot hole without tapping and with a smaller diameter than that of the screw (4.5 mm) and a different thread, and with the tapping with the same diameter as that of the screw (5.5 mm) and equal or different thread presented a statistical difference with a higher value of the insertion torque in the group in which the tapping was not performed. As for the pulling force of the $5.5 \mathrm{~mm}$ screw, the non-tapping of the pilot hole resulted in statistical difference with the same diameter of the screw (5.5 mm) and with a different thread of the screw. The pullout force on the $6.5 \mathrm{~mm}$ screw was higher in the group where the pilot hole was not tapped according to the non-parametric Kruskal-Wallis test, with significance level of $p<0.05$ in the comparison of the groups. Conclusions: Pilot hole tapping reduced insertion torque and pullout resistance of the pedicle screw influencing the fixation with tapping with the same screw diameter and different thread design.
\end{abstract}

Keywords: Spine; Bone screws; Spinal fusion.

\section{RESUMO}

Objetivo: Avaliar o torque de inserção e a força de arrancamento de cada parafuso com diferentes diâmetros e machos. Métodos: Foram utilizados no estudo blocos de poliuterano com orifício piloto de $2,7 \mathrm{~mm}$, sendo feito um grupo experimentais com 5 blocos sendo avaliado o torque de inserção com torquímetro e avaliado o arrancamento de cada parafuso de parafusos Globus 5,5mm e 6,5mm. Resultados: A comparação do torque de inserção nos parafusos de 5,5mm entre a utilização de orifício piloto sem macheamento e o macheamento com diâmetro inferior ao diâmetro do parafuso $(4,5 \mathrm{~mm})$ e rosca diferente, e com o macheamento com diâmetro igual do parafuso $(5,5 \mathrm{~mm})$ e com rosca igual ou diferente apresentou diferença estatística com maior valor do torque de inserção no grupo em que o macheamento não foi realizado. Na força de arrancamento do parafuso $5.5 \mathrm{~mm}$ o não macheamento do orifício piloto apresentou diferença estatística com o mesmo diâmetro do parafuso $(5,5 \mathrm{~mm})$ e rosca diferente do parafuso. A força de arrancamento no parafuso $6,5 \mathrm{~mm}$ foi maior no grupo em que o orifício piloto não foi macheado utilizando o teste não paramétrico de Kruskal Wallis com nível de significância adotado (p < 0,05) na comparação dos grupos. Conclusões: O macheamento do orifício piloto diminuiu o torque de inserção e resistência ao arrancamento do parafuso pedicular influenciando a fixação com macheamento com o mesmo diâmetro do parafuso e desenho de rosca diferente.

Descritores: Coluna vertebral; Parafusos ósseos; Fusão vertebral.

\section{RESUMEN}

Objetivo: Evaluar el torque de inserción y la fuerza de extracción de cada tornillo con diferentes diámetros y machos. Métodos: Se utilizaron en el estudio bloques de poliuretano con agujero piloto de 2,7 mm. Se formó un grupo experimental con 5 bloques, y el torque de inserción se evaluó con llave de par y se analizó la fuerza de extracción de cada tornillo Globus de 5,5 mm e 6,5 mm. Resultados: La comparación del torque de inserción en los tornillos de $5,5 \mathrm{~mm}$ con agujero piloto sin taladramiento y con un diámetro más pequeño que el del tornillo $(4,5 \mathrm{~mm})$ y un roscado diferente, y con el taladramiento con el mismo diámetro que el del tornillo (5,5 mm) y con el roscado igual o diferente presentó una diferencia estadística con un valor más alto del torque de inserción en el grupo en el que no se realizó taladramiento. En cuanto a la fuerza de extracción del tornillo $5,5 \mathrm{~mm}$ el no taladramiento del agujero piloto resultó en una diferencia estadística solamente con el mismo diámetro del tornillo $(5,5 \mathrm{~mm})$ y con roscado diferente del tornillo. La fuerza de extracción en el tornillo de $6,5 \mathrm{~mm}$ fue mayor en el grupo que en el agujero piloto no tuvo taladramiento, de acuerdo con la prueba no paramétrica de Kruskal-Wallis, con nivel de significación de $p<0,05$ en la comparación de los grupos. Conclusiones: El taladramiento del agujero piloto redujo el torque de inserción y la resistencia a la extracción del tornillo pedicular, lo que influye con la fijación con taladramiento con el mismo diámetro del tornillo e diferentes diseños de roscado.

Descriptores: Columna vertebral; Tornillos óseos; Fusión vertebral. 


\section{INTRODUCTION}

Spinal fixation systems that use the vertebral pedicle as the implant anchor point have been used extensively in the spinal surgery environment. ${ }^{1}$ The insertion torque and the pullout strength of pedicle screws is influenced by different factors, such as bone mineral density, screw geometry, and pilot hole preparation..$^{2-4}$

Tapping consists of using a tool to cut the inner surface of the pilot hole for the adaptation of the screw thread. This technical step for the placement of screws in the bones originated from osteosynthesis of the long bones and was adapted for spine surgery. However, tapping the pilot hole with an instrument of outer diameter equal to the outer diameter of the pedicle screw reduces the pullout strength of the pedicle screw. ${ }^{5-9}$ The use of tapping with a diameter less than the outer diameter of the screw has shown to be advantageous by increasing secureness during the insertion of the pedicle screws and by not reducing the resistance of these implants to pullout. ${ }^{10}$ Another variable that has been evaluated is tap thread design and it has been observed that the use of a tap with thread design different from the screw thread design, even though of smaller diameter in relation to the outer diameter of the screw, causes a reduction in the pullout strength of the implants.

The objective of this study was to experimentally evaluate the influence of tap diameter and thread design on the insertion torque and pullout strength of two modalities of pedicle screws, 5.5 and $6.5 \mathrm{~mm}$, used in spinal fixation systems.

\section{METHODS}

The experimetal groups were formed according to the mode of pilot hole, the external diameter of screw used (5.5 and 6.5mm), the diameter and design of the tap thread. Each experimental group was made up 5 polyurethane blocks. (Figure 1)

We used polyurethane blocks with a density of 10 PCF or $0.16 \mathrm{~g} / \mathrm{cm}^{3}$ and diameter of $5 \mathrm{~cm} \times 8 \mathrm{~cm} \times 5 \mathrm{~cm}$ (Nacional Ltda.) in our biomechanical trial. A $2.7 \mathrm{~mm}$ perforation was drilled in the center of the upper face of the polyurethane block to make the pilot hole. The pilot hole was made according to the experimental group as follows: 1 - without tapping, 2 - tapping with a tap smaller in diameter than the screw and with the same thread design, 3 - tapping with a tap smaller in diameter than the outer diameter of the screw and with a different thread design, 4 - tapping with a tap of the same diameter as the outer diameter of the screw and with the same thread design, and 5 - tapping with a tap of the

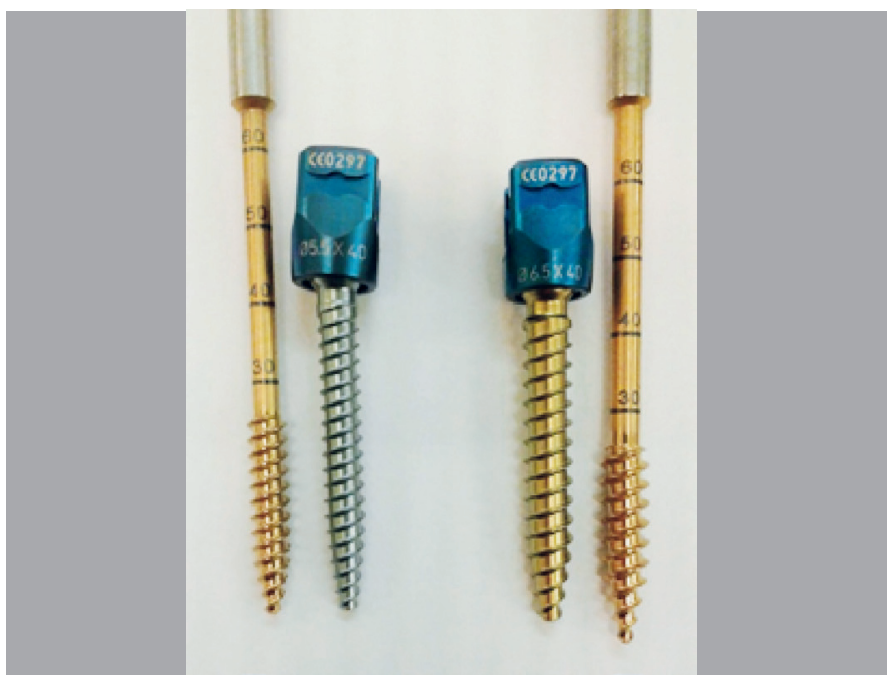

Figure 1. Photograph of the screws and respective taps used in the study - on the left, the tap and the $5.5 \mathrm{~mm}$ screw and, on the right, the tap, and the 6.5 $\mathrm{mm}$ screw (Globus). Screw characteristics $-5.5 \mathrm{~mm}$ screw: screw core 4.5 $\mathrm{mm}$, between threads $1.8 \mathrm{~mm} ; 6.5 \mathrm{~mm}$ screw: screw core $5.0 \mathrm{~mm}$, between threads $2.1 \mathrm{~mm}$. $6.5 \mathrm{~mm}, 5.5 \mathrm{~mm}$, and $4.5 \mathrm{~mm}$ taps were used. same outer diameter as the screw and with a different thread design. Globus-type 5.5 and $6.5 \mathrm{~mm}$ screws were used in the study. The screws were inserted after preparation of the pilot hole according to experimental group.

The insertion torque was evaluated during the insertion of the screw by means of a key attached to a digital electronic torque meter (TL-500/MKT-1 Mackena Corporation, São Paulo, Brazil). The maximum insertion torque was recorded.

The pullout strength was evaluated using the EMIC® universal test machine (DL 10000; EMIC, São José dos Pinhais, PR, Brazil). A rod was attached to the head of the screw and the pullout force was applied vertically. The pullout force was applied at a velocity of $2.0 \mathrm{~mm} / \mathrm{min}$ until the screw was pulled out of the polyurethane block. (Figure 2)

Kruskal-Wallis non-parametric tests were performed to compare the "pullout strength" and "insertion torque" variables between the screw and diameter groups.

In the Kruskal-Wallis test, p-values less than the adopted level of significance (generally 0.05) meant that at least one of the groups differed from the others. To further define these differences, Dunn's multiple comparisons post-test was performed and comparisons with p-values less than the adopted level of significance (generally 0.05) were indicative of a difference between groups observed.

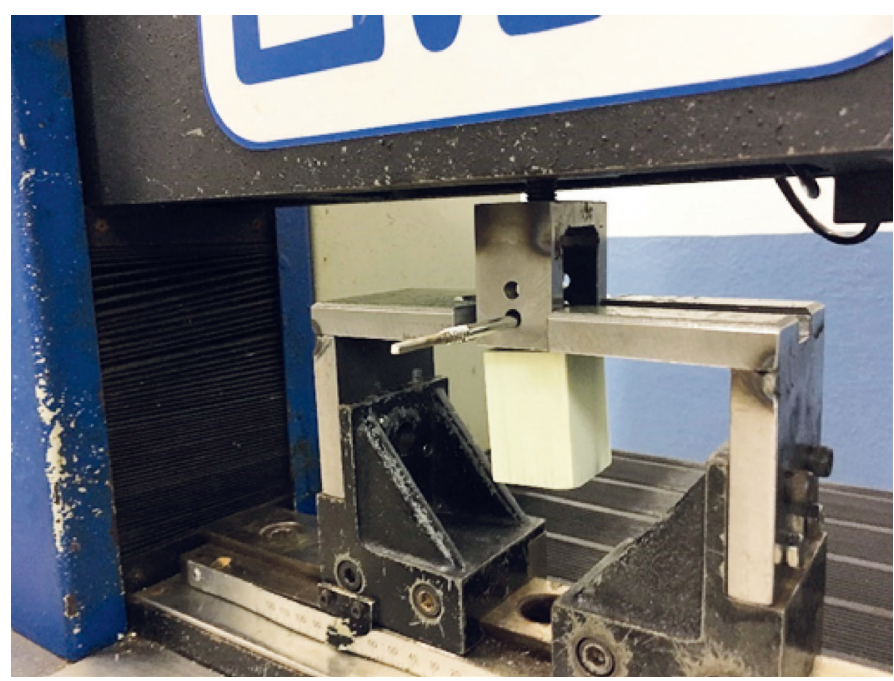

Figure 2. Polyurethane block individually mounted with screw for the application of pure axial load to measure pullout strength.

\section{RESULTS}

The insertion torque and pullout strength values of the $5.5 \mathrm{~mm}$ and $6.5 \mathrm{~mm}$ screws are shown in Table 1 and in Figures 3 and 6. A statistical difference was observed in the $5.5 \mathrm{~mm}$ screw experimental group in relation to the mean insertion torque values using a tap with a diameter less than that of the screw $(4.5 \mathrm{~mm})$ and with a different thread design. However, no statistical difference was observed in relation to the insertion torque using a tap with the same diameter as the screw $(5.5 \mathrm{~mm})$ and with a different thread design, a greater insertion torque value having been observed for a tap with the same diameter as the screw $(5.5 \mathrm{~mm})$ and with the same thread design.

In the experimental group of screws with a $5.5 \mathrm{~mm}$ diameter, we observed a statistical difference when comparing the insertion torque using a tap of the same diameter and a different thread design with that using a tap with a diameter less than the diameter of the screw $(4.5 \mathrm{~mm})$ and a different thread design, and with that using a tap with a diameter equal to the screw $(5.5 \mathrm{~mm})$ and either the same or a different thread design with a lower insertion torque value. (Figure 3)

In the $6.5 \mathrm{~mm}$ screw experimental group, a statistical difference was observed between the insertion torque of the tap with the same diameter as the screw $(6.5 \mathrm{~mm})$ and a different thread 
design and that of the tap with a diameter less than that of the screw $(5.5 \mathrm{~mm})$ and a different thread design. The lowest insertion torque was observed with the tap of the same diameter as the screw $(6.5 \mathrm{~mm})$ and a different thread design. In addition, a statistical difference was observed between the insertion torque without tapping and that with a tap of the same diameter as that of the screw $(6.5$ $\mathrm{mm}$ ) with the same thread design. The highest insertion torque was observed when making the pilot hole without tapping. The insertion torque was lower in the groups in which the pilot hole was tapped with a different thread design. (Figure 4)

The pullout strength in the group of $5.5 \mathrm{~mm}$ screws presented a statistical difference when the tap had a diameter less than the diameter of the screw $(4.5 \mathrm{~mm})$ or equal to the diameter of the screw $(5.5 \mathrm{~mm})$, regardless of thread design. (Figure 5) No tapping of the pilot hole only presented a statistical difference with the same diameter as the screw $(5.5 \mathrm{~mm})$ and a different thread design, with a greater insertion torque value in the group in which tapping was not used. (Figure 3)

In the group of $6.5 \mathrm{~mm}$ screws, we observed a statistical difference in pullout strength between tapping with a diameter less than the diameter of the screw $(5.5 \mathrm{~mm})$ or equal to the diameter of the screw $(6.5 \mathrm{~mm})$, regardless of thread design. (Figure 6) A statistical difference was observed between tapping with a diameter equal to the diameter of the screw $(6.5 \mathrm{~mm})$ when the thread design was either the same or different from that of the screw. (Figure 4) The pullout strength was lower in the groups where the pilot hole was tapped with a different thread.

Table 1. Mean pullout strength and mean insertion torque of 5.5 and 6.5 screws. Groups: 1 - without tapping, 2 - tapping with a tap smaller in diameter than the screw and with the same thread design, 3 - tapping with a tap smaller in diameter than the outer diameter of the screw and with a different thread design, 4 - tapping with a tap of the same diameter as the outer diameter of the screw and with the same thread design, and 5 - tapping with a tap of the same outer diameter as the screw and with a different thread design.

\begin{tabular}{|c|c|c|c|c|}
\hline \multicolumn{5}{|c|}{ Screws } \\
\hline \multirow[b]{2}{*}{ Groups } & \multicolumn{2}{|c|}{$5.5 \mathrm{~mm}$} & \multicolumn{2}{|c|}{$6.5 \mathrm{~mm}$} \\
\hline & $\begin{array}{l}\text { Mean pullout } \\
\text { strength }\end{array}$ & $\begin{array}{c}\text { Mean insertion } \\
\text { torque }\end{array}$ & $\begin{array}{l}\text { Mean pullout } \\
\text { strength }\end{array}$ & $\begin{array}{c}\text { Mean insertion } \\
\text { torque }\end{array}$ \\
\hline 1 & 615.336 & 0.6482 & 731.632 & 0.9846 \\
\hline 2 & 607.212 & 0.6216 & 677.954 & 0.9846 \\
\hline 3 & 581.616 & 0.6086 & 699.772 & 0.9738 \\
\hline 4 & 587.912 & 0.5758 & 667.326 & 0.9402 \\
\hline 5 & 536.788 & 0.5126 & 645.184 & 0.8908 \\
\hline
\end{tabular}

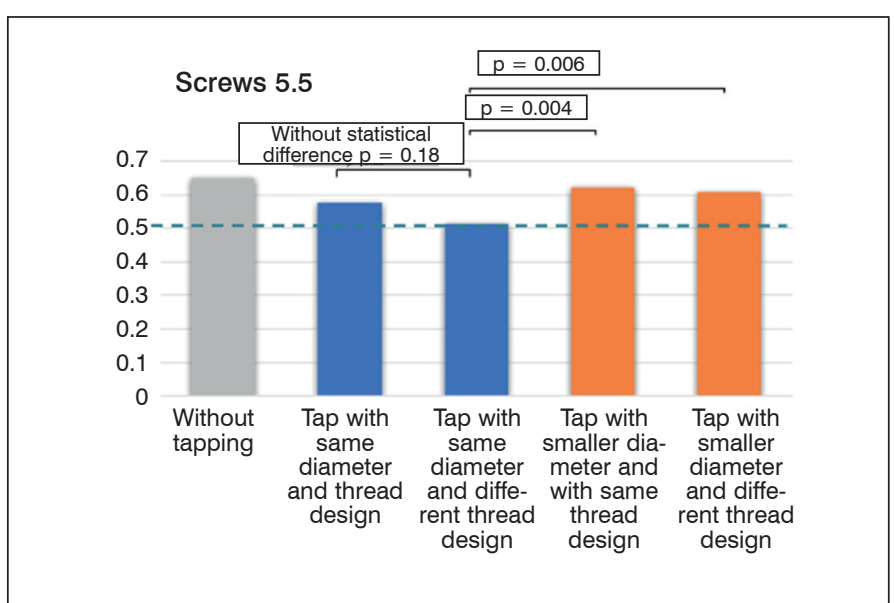

Figure 3. Mean insertion torque of the $5.5 \mathrm{~mm}$ screws with lines indicating $p$-values less than the adopted significance level $(p<0.5)$ showing evidence of difference between the groups observed. Groups: 1 - without tapping, 2 - tapping with tap of diameter less than that of the screw and with the same thread design, 3 - tapping with tap of diameter less than the outer diameter of the screw with a different thread design, 4 - tapping with tap of the same outer diameter as the screw and the same thread design, and 5 -tapping with tap of the same outer diameter as the screw and a different thread design.

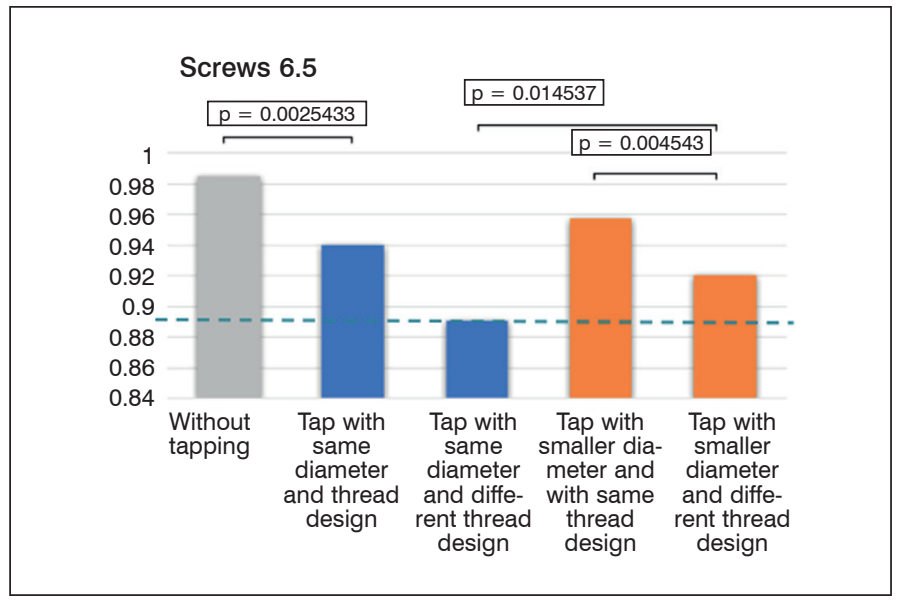

Figure 4. Mean insertion torque of the $6.5 \mathrm{~mm}$ screws with lines indicating $p$-values less than the adopted significance level $(p<0.5)$ showing evidence of difference between the groups observed. Groups: 1 - without tapping, 2 - tapping with tap of diameter less than that of the screw and with the same thread design, 3 - tapping with tap of diameter less than the outer diameter of the screw with a different thread design, 4 - tapping with tap of the same outer diameter as the screw and the same thread design, and 5 - tapping with tap of the same outer diameter as the screw and a different thread design.

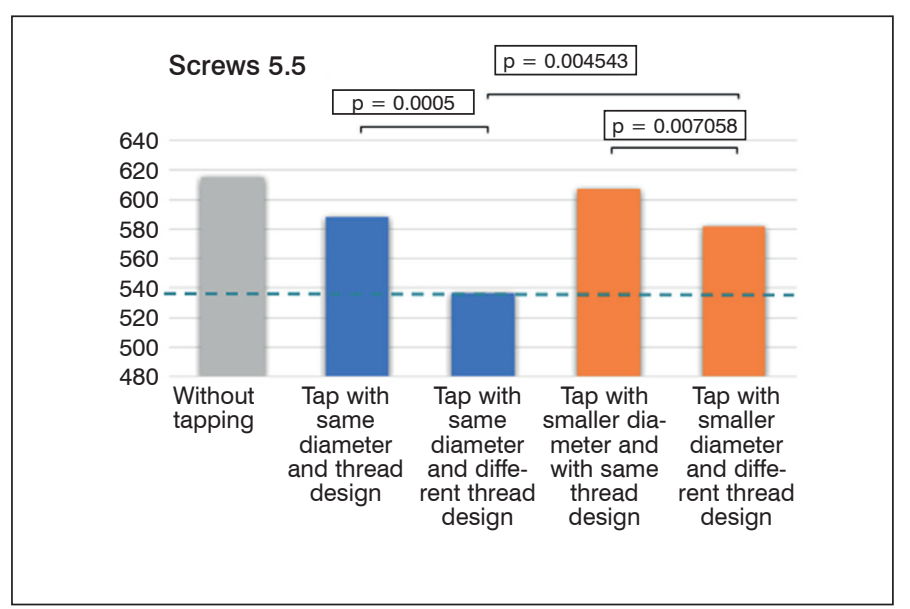

Figure 5. Mean pullout strength the $5.5 \mathrm{~mm}$ screws with lines indicating $\mathrm{p}$-values less than the adopted significance level $(p<0.5)$ showing evidence of difference between the groups observed. Groups: 1 - without tapping, 2 - tapping with tap of diameter less than that of the screw and with the same thread design, 3 - tapping with tap of diameter less than the outer diameter of the screw with a different thread design, 4 - tapping with tap of the same outer diameter as the screw and the same thread design, and 5 - tapping with tap of the same outer diameter as the screw and a different thread design.

The pullout strength of the $5.5 \mathrm{~mm}$ and $6.5 \mathrm{~mm}$ screws was influenced by the design of the tap thread in relation to the screw thread, with tapping at a diameter less than or equal to the diameter of the screws reducing the strength. However, non-tapping of the pilot hole increased the resistance of the screws to pullout.

\section{DISCUSSION}

Tapping of the pilot hole reduced the insertion torque and pullout strength in accordance with the technical steps performed for spine fixation. ${ }^{1}$ In our study, we sought to establish a correlation between the insertion torque and the pullout strength of the screw, using different tap diameters and geometries in relation to the outer diameter of the screw.

In our trial, we observed that the use of tapping as compared to non-tapping of the pilot hole reduced the resistance and insertion 


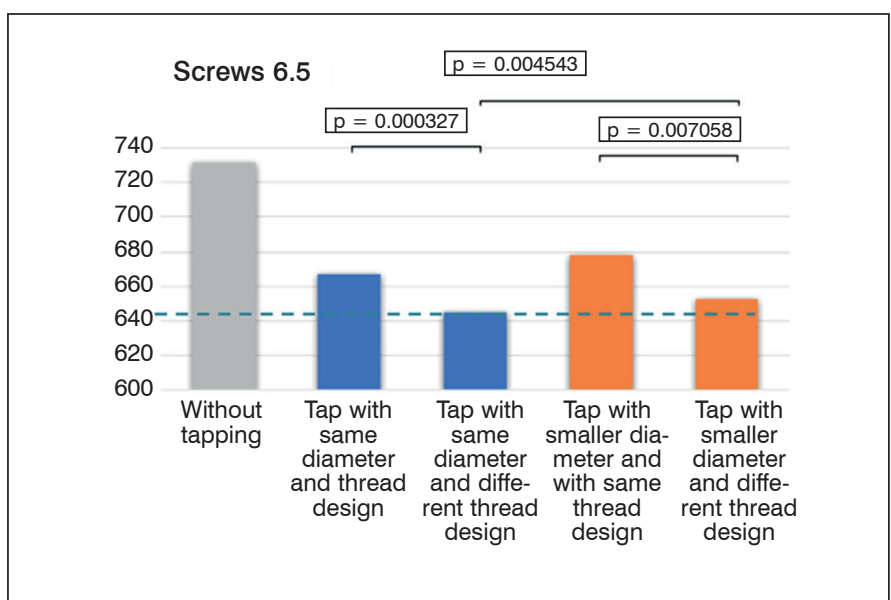

Figure 6. Mean pullout strength of the $6.5 \mathrm{~mm}$ screws with lines indicating $p$-values less than the adopted significance level $(p<0.5)$ showing evidence of difference between the groups observed. Groups: 1 - without tapping, 2 - tapping with tap of diameter less than that of the screw and with the same thread design, 3 - tapping with tap of diameter less than the outer diameter of the screw with a different thread design, 4 - tapping with tap of the same outer diameter as the screw and the same thread design, and 5 - tapping with tap of the same outer diameter as the screw and a different thread design.

torque of the screws. Additionally, we observed a reduction in insertion torque and resistance of the screws using a tap with a diameter less than the outer diameter of the screw and with a different thread design. In the literature, it has been reported as a factor in the decrease in the resistance of screws to pullout., 2,-8,10 On the other hand, there is a study of the reduction of the implant pullout strength with tapping of the pilot hole in lumbar vertebrae with osteoporosis. ${ }^{9}$

There is controversy around the relationship between implant insertion torque and pullout strength in the literature that deals with this subject. There are trials that correlate the above parameters, ${ }^{11-15}$ as opposed to others that present results that do not agree, in which no influence of the pilot hole on pullout strength was observed. ${ }^{16,17}$

The biomechanical evaluation was structured to simulate the insertion torque and pullout strength of the implants, and though not producing the physiological conditions of the application of force on the fixation systems, it allows the comparison and reliable assessment between the parameters evaluated. The pullout strength of the implants is influenced by various factors, such as bone tissue quality (osteoporosis), preparation of the pilot hole (diameter, depth, and tapping of the perforation), and the design and diameter of the implant used. ${ }^{2-6}$ The results observed in our trials confirm the hypothesis that the diameter and the geometry of the tapping in relation to the pedicle screw have an influence, reducing the pullout strength and insertion torque of the implants in the group in which the pilot hole was not tapped. These results serve as an alert to consider the influence of the pilot hole.

Screw pullout is a method widespread in the literature and a way to objectively demonstrate resistance of the screw to axial load. With this, we observed that the pullout strength of screws of $5.5 \mathrm{~mm}$ and $6.5 \mathrm{~mm}$ was influenced by the design of the tap thread in relation to the screw thread, with tapping of a diameter less than or equal to the diameter of the screws used.

\section{CONCLUSION}

The tapping of the pilot hole reduces the insertion torque and pullout strength of the pedicle screw. In addition, the geometry of the thread and the diameter of the tap interfere with the insertion torque and pullout of the screw, influencing fixation.

All authors declare no potential conflict of interest related to this article.

CONTRIBUTION OF THE AUTHORS: Each author made significant individual contributions to this manuscript. HLD (0000-0003-4274-0130)* and RFM (0000-0002-1863-9908)* were the main contributors to the writing of the manuscript. RPP $(0000-0002-0623-3003)^{\star}$ performed the statistical data analysis and was responsible for the intellectual concept of the study. HLD, RFM, and RPP evaluated the data and conducted the bibliographical. ACS (0000-0002-3119-2362)* Realization and orientation in mechanical tests. *ORCID (Open Researcher and Contributor ID).

\section{REFERENCES}

1. Pfeiffer M, Gilbertson LG, Goel VK, Griss P, Keller JC, RykennTC, et al. Effect of specimen fixation method on pullout tests of pedicle screws. Spine (Phila Pa 1976). 1996;21(9):1037-44.

2. Benzel E. Biomechanics of spine stabilization. New York: Thieme, 2001

3. Brantley AG, Mayfield JK, Koeneman JB, Clark KR. The effects of pedicle screw fit. An in vitro study. Spine (Phila Pa 1976). 1994;19(15):1752-8.

4. Schtzker J, Horne J, Summer-smith G. The reaction of cortical bone to compression by screw threads. Clin Orthop Relat Res. 1975;(111):263-5.

5. Derincek A, Wu C, Mehbod A, Transfeldt EE. Biomechanical comparison of anatomic trajectory pedicle screw versus injectable calcium sulfate graft-augmented pedicle screw for salvage in cadaveric thoracic bone. J Spinal Disord Tech. 2006;19(4):286-91.

6. Koranyi E, Bowman C, Knecht C, Janssen M. Holding power of orthopedic crews in boné Clin Orthop Relat Res. 1970;(72):283-6.

7. Oktenoglu B, Ferreira L, Andalkar B, Bzer A, Sarioglu A, Benzel E. Effects of hole preparation on screw pullout resistance and insertional torque: a biomechanical study. J Neurosurg. 2006;94 (1 Suppl): 91-6.

8. SheaTM, Laun J, Gonzalez-Blohm SA, Doulgeris JJ, Lee WE 3rd, Aghayev K, et al. Designs and techniques that improve the pullout strength of pedicle screws in osteoporotic vertebrae: current status. Biomed Res Int. 2014;2014:748393.

9. Phan K, Hogan J, Maharaj M, Mobbs RJ. Cortical Bone Trajectory for Lumbar Pedicle Screw Placement: A Review of Published Reports. Orthop Surg. 2015;7(3):213-21.
10. Bohl DD, Basques BA, Golinvaux NS, Toy JO, Matheis EA, Bucklen BS, et al. Undertapping of lumbar pedicle screw can result in tapping with a pitch that differs from that of the screw, wich decreases screw pullout force. Spine (Phila Pa 1976). 2015 Jun 15:40(12):729-34.

11. Hsu CC, Chao CK, Wang JL, Hou SM, TsaiYT, Lin J. Increase of pullout strength of spinal pedicle screws with conical core: biomechanical tests and finite element analyses. $J$ Orthop Res. 2005;23(4):788-94.

12. Kim YY, Choi WS, Rhyu KW. Assessment of pedicle screw pullout strength based on various screw designs and bone densities-na ex vivo biomechanical study. Spine J. 2012;12(2):164-8.

13. Daftari TK, Horton WC, Hutton WC. Correlations between screw hole preparation, torque of insertion, and pullout strength for spinal screws. J Spinal Disord. 1994;7(2):139-45.

14. Ryken TC, Goel VK, Clausen JD, Traynelis VC. Assesment of unicortical and bicortical fixation in a quasistatic cadaver model. Role of bone mineral density and screw torque. Spine (Phila Pa 19760). 1995;20(17):1861-7.

15. Ryken T, Clausen J, Traynelis VC, Goel VK. Biomechanical analysis of bone mineral density, insertion technique, screw torque, an holding strenght of anterior cervical plate screw. J Neurosurg. 1995;83(2):324-9

16. ZdeblickTA, Kunz DN, Cooke ME, McCabe R. Pedicle screw pullout strenght. Correlation with insertional torque. Spine (Phila Pa 1976). 1993:18(12):1673-6.

17. Inceoglu S, Ferrara L, McLain RF. Pedicle screw fixation strength: pullout versus insertional torque. Spine J. 2004;4(5):513-8. 